\title{
Recyclable waste pickers: life and work in light of the social determinants of health
}

\author{
Catadores de material reciclável: vida e trabalho à luz dos determinantes sociais de saúde
}

Segregadores de residuos sólidos: vida y trabajo a la luz de los determinantes sociales de la salud

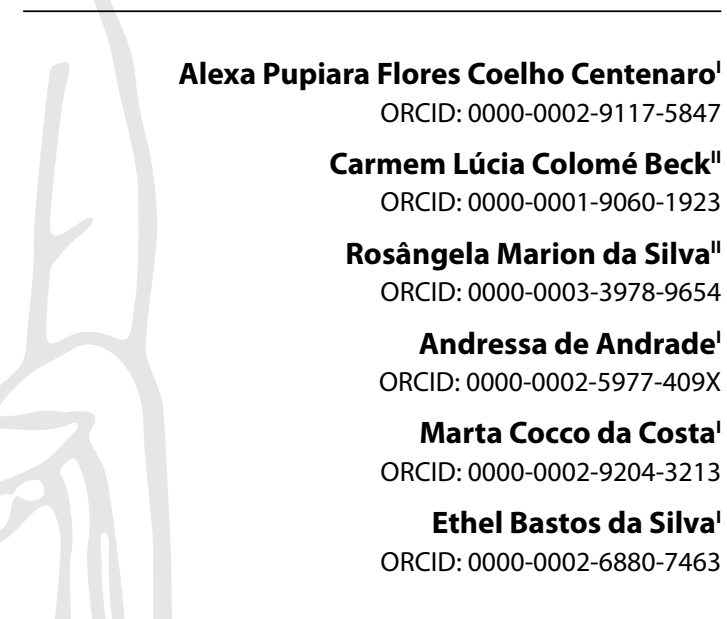

'Universidade Federal de Santa Maria. Palmeira das Missões, Rio Grande do Sul, Brazil.

"Universidade Federal de Santa Maria. Santa Maria, Rio Grande do Sul, Brazil.

How to cite this article: Centenaro APFC, Beck CLC, Silva RM, Andrade A, Costa MC, Silva EB. Recyclable waste pickers: life and work in light of the social determinants of health.

Rev Bras Enferm. 2021;74(6): e20200902. https://doi.org/10.1590/0034-7167-2020-0902

Corresponding author:

Alexa Pupiara Flores Coelho Centenaro E-mail: alexa.coelho@ufsm.br

EDITOR IN CHIEF: Antonio José de Almeida Filho ASSOCIATE EDITOR: Priscilla Broca

Submission: $09-04-2020$

Approval: 03-11-2021

\begin{abstract}
Objectives: to know how the social determinants of health relate to the context of life and work of recyclable waste pickers. Methods: a qualitative study, derived from ConvergentCare Research, conducted with waste pickers from two recycling associations in the South of Brazil. We used systematic participant observation, semi-structured interviews, and convergence groups. The analysis followed the steps of Seizure, Synthesis, Theorization, and Transfer. Results: advanced age, precarious self-care, gender inequalities, violence, and family conflicts have shown to be elements linked to the individual, behavioral, and social network determinants. Determinants connected to living and working conditions were related to poor access to education and formal work, as well as to the daily occupational risks in recycling. The lack of labor rights and public policies represented macro-determinants. Final Considerations: social and economic deficiencies are potentiated in the context of life and work of waste pickers, strongly related to their determinants.

Descriptors: Social Determinants of Health; Solid Waste Segregators; Occupational Health; Gender-Based Violence; Nursing.
\end{abstract}

\section{RESUMO}

Objetivos: conhecer como os determinantes sociais de saúde se relacionam com o contexto de vida e trabalho dos catadores de material reciclável. Métodos: estudo qualitativo, oriundo de uma Pesquisa Convergente-Assistencial, realizado com catadores de duas associações de reciclagem do Sul do Brasil. Foram utilizadas observação sistemática participante, entrevistas semiestruturadas e grupos de convergência. A análise seguiu os passos: Apreensão, Síntese, Teorização e Transferência. Resultados: idade avançada, autocuidado deficitário, iniquidades de gênero, violência e conflitos familiares se evidenciaram como elementos atrelados aos determinantes individuais, comportamentais e de redes sociais. Determinantes adstritos às condições de vida e trabalho se mostraram relacionados ao pouco acesso à educação e trabalho formal, bem como ao cotidiano de riscos ocupacionais na reciclagem. Carência de direitos trabalhistas e de políticas públicas representou macrodeterminantes. Considerações Finais: carências sociais e econômicas são potencializadas no contexto de vida e trabalho dos catadores, relacionando-se fortemente aos seus determinantes.

Descritores: Determinantes Sociais da Saúde; Catadores; Saúde do Trabalhador; Violência de Gênero; Enfermagem.

\section{RESUMEN}

Objetivos: conocer como los determinantes sociales de la salud se relacionan con el contexto de vida y trabajo de segregadores de residuos sólidos. Métodos: estudio cualitativo, oriundo de una Investigación Convergente-Asistencial, realizado con segregadores de residuos sólidos de dos asociaciones de reciclaje del Sur Brasileño. Utilizadas observación sistemática participante, entrevistas semiestructuradas y equipos de convergencia. Análisis siguió los pasos: Aprehensión, Síntesis, Teorización y Transferencia. Resultados: edad avanzada, autocuidado deficitario, iniquidades de género, violencia y conflictos familiares se evidenciaron como elementos enlazados a determinantes individuales, comportamentales y de redes sociales. Determinantes adscritos a condiciones de vida y trabajo se mostraron relacionados al poco acceso a educación y trabajo formal, bien como al cotidiano de riesgos ocupacionales en reciclaje. Carencia de derechos laborales y de políticas públicas representó macrodeterminantes. Consideraciones Finales: carencias sociales y económicas son potenciadas en el contexto de vida y trabajo de los segregadores de residuos sólidos, relacionándose fuertemente a sus determinantes.

Descriptores: Determinantes Sociales de la Salud; Segregadores de Residuos Sólidos; Salud Laboral; Violencia de Género; Enfermería. 


\section{INTRODUCTION}

Recyclable waste pickers are part of a vulnerable social group concerning health, education, and living and working conditions $\mathbf{s}^{(1-2)}$. In Brazil, we estimate that about 300 thousand people work with recyclable material and that they are present in about $89 \%$ of Brazilian municipalities. They are predominantly men, self-declared black or brown, with age range between the third and fourth decade of life. The rate of illiteracy or low education in this segment is higher than the average of the population. Most part work informally, with low incomes ${ }^{(3)}$.

Recent evidence has shown that waste pickers of recyclable material have a high prevalence of occupational disease (especially chronic and infectious diseases related to the environment), provoked by little access/use of health services, and poor living, housing and working conditions $^{(4-7)}$. Also, studies have shown that waste pickers of recyclable material have life trajectories marked by exclusion from the labor market and lack of opportunities and are also vulnerable to powerful agents of suffering related to prejudice and stigma for working with what society calls "waste" ${ }^{\prime \prime(8-9)}$.

It contributes to the marginalization of a worker who is not effectively supported by public health policies regarding their needs ${ }^{(9)}$. Most parts of the recyclable waste pickers work outside the formal waste system, putting their health at risk due to the need to provide for their livelihood ${ }^{(1)}$. Because of the multiple vulnerabilities of life and work of this population, the concept of "social determinants of health" (SDOH) is crucial for the understanding of the elements that surround the dynamics of health and illness.

SDOHs concern the conditions under which people are born, grow, work, live and age, attached to a broader and more complex set of forces and systems that direct living conditions. This phenomenon includes economic policies and methods, social norms and policies ${ }^{(10)}$, factors that cumulatively affect the process of health and illness of people and populations, establishing inequalities and health disparities.

The present study is based on the prerogatives of the theoretical-conceptual framework of SDOH established by Dahlgren and Whitehead and assumed by the World Health Organization in 2005. This model comprises the SDOH system with individuals or groups as the center of a set of forces that involves from the elements most attached to the subjects (such as personal, biological, and behavioral factors) to the macro-determinants, represented by historical, cultural, social, and economic factors that are established in societies or even in the world ${ }^{(11)}$.

$\mathrm{SDOH}$ s are directly related to health access and promotion ${ }^{(12)}$. For the promotion of nursing care, knowing the SDOHs of a population can reveal factors that enhance or make your health more vulnerable and that can be modified ${ }^{(13)}$. To that end, this element must be discussed in the health field and nursing, given the challenge of considering the singularities of the individuals (such as the waste pickers of recyclable material) and their life contexts, since they are in scenarios influenced by precarious socioeconomic and environmental factors.

\section{OBJECTIVES}

To know how the social determinants of health relate to the context of life and work of waste pickers of recyclable material.

\section{METHODS}

\section{Ethical aspects}

We conducted this research with the formal consent of recycling associations. The local research ethics committee, in compliance with the precepts of resolutions 466/2012 and 510/2016 of the National Health Council approved the study, which deals with research with human beings. We identified the participants by pseudonyms chosen by them.

\section{Type of study}

It is a qualitative study based on the methodological framework of Convergent- Care Research (CCR), a method that allows the conduction of concomitant investigations to care practices ${ }^{(14)}$. We used the guidelines for qualitative studies (COREQ).

\section{Study scenario}

The scenario of the study included two recycling associations located in the Southern Region of Brazil. Both shared the same recycling shed and the same work process. They had a population of 23 waste pickers, who took turns in the work in the recycling shed (where they received, separated, pressed, and stored the recyclable material) and the two trucks (the trucks did the selective collection of recyclable material in the municipality, supported by a contract with the city hall).

\section{Study participants}

The participants were the waste pickers members of the associations, including those who worked in the shed and trucks. Since all of them were over 18 years old and had vocal and cognitive conditions for communication, we chose to include all in the study. Among the 23 workers, one woman was away due to pregnancy during the data production period and three chose not to participate in the research, so the sample was composed of 19 waste pickers.

\section{Data collection and organization}

Data production took place from August to November 2017, through the triangulation of three methodological tools: systematic participant observation, semi-structured interviews, and convergence groups.

The systematic participant observation took place between August and September 2017, totaling 115 hours in the field with 19 workers who signed the Informed Consent Form. The researcher was inserted in the recycling shed, in the trucks' itineraries, and followed team meetings. We used an observation script focused on working conditions and worker interactions with the environment, tasks, and labor organization. The data were compiled in Field Journal and called "observation notes"(ON). We completed the observation according to the criterion of theoretical saturation ${ }^{(15)}$.

We conducted semi-structured interviews from September to October 2017. There were 18 interviews in the room dedicated to the associations' thrift shop, which guaranteed comfort and privacy 
to the participants. We conducted the interviews with the support of a semi-structured script in the following topics: life trajectory, admission into work; perceptions and feelings of the worker about their work; and elements of work that interfere with their health. We considered the first interview a pilot test and, given the need for adjustments to the question script, was deleted from the database. Interviews lasted around 28 minutes and we recorded them with the consent of the participants. Their interruption occurred according to the exhaustion criterion, i.e., when all eligible participants were approached $^{(15)}$. At the end of the interviews, we performed a pre-analysis and prepared a summary of the content by topics, and we read them during the convergence groups for data validation.

Then, we organized the convergence groups, a tool widely used in the PCA for enabling a group interaction for generating imminent data research, in conjunction with the process of reflection of the subjects. The workers were divided into two groups due to the number of participants, because we considered that the process of speech and participation would be facilitated in smaller groups. We met each group in November 2017, with the same semi-structured script, which was focused on collective reflection about the environmental elements, organizations and personnel that could affect the health of the waste picker.

Each meeting had an average duration of one hour and thirty minutes and was mediated by the principal investigator and three research assistants. Two assistants had the role of conducting records throughout the debates, and another was responsible for preparing a summary of the content, which was read at the end of the meeting for data validation. The meetings took place in the cafeteria of the association, and we recorded them with the consent of the participants.

\section{Data analysis}

We analyzed the observation, interview, and group notes according to the steps proposed by the PCA: Seizure, Synthesis, Theorization, and Transfer ${ }^{(14)}$.

The Seizure begins with the production of data and corresponds to the organization of Information ${ }^{(14)}$. The Express Scribe Transcription Software made the transcription in full and transported them to the Microsoft Word 2010 text editor, along with the field diary. A thorough reading of the material was followed until we elected codes representing the content.

In the synthesis, the researcher subjectively analyzes the seized data, forming the first categorizations ${ }^{(14)}$. The chromatic technique was chosen, which assigns a color to each selected code. After coding the raw data and sorting by color, the fragments were cut out and pasted into posters, under which formed the first groupings by semantic affinity.

In the Theorizing phase, the researcher seeks to discover the values and meanings embedded in the observed data, formulating assumptions and theories ${ }^{(14)}$. At this stage, we organized data in the light of the Dahlgren and Whitehead's SDOHs model, according to which the determinants are arranged in layers, the first of which reflects the individual sphere of the individuals who relate socially ${ }^{(11)}$. The first layers are closer to individual determinants, while the last layers, more distant, are closer to macro-determinants ${ }^{(11)}$.
The first layer is constituted of the individual determinants (such as age, gender, genetic inheritances). The second is formed by individual behaviors and lifestyles. The third is social networks. The fourth consists of living and working conditions. The fifth and last, outermost layer is formed by the macro-determinants, structural elements that are established at the level of society (such as culture, economy, environment, among others) ${ }^{(11)}$.

We made notes under the posters, and the reflections led to an understanding of how the data found met the proposed model.

Finally, in the fourth and last phase, Transfer, we performed the inference for practice and projection for new research ${ }^{(14)}$, through comparison with the national and international literature.

We organized the results into two categories: individual and family trajectories demarcated by $\mathrm{SDOH}$; and living and working conditions and the interface with macro-determinants.

\section{RESULTS}

Among the 19 participants in this study, there was a predominance of women ( $n=15)$, with partner $(n=14)$, with child(ren) ( $n$ $=16$ ). Six were Caucasian, four were swarthy, four were brown, three were black, and two were light brown. The average age of the waste pickers was 43.7 years, the youngest worker was 30 years old, and the oldest was 62 years old. Education: nine had an uncompleted elementary school, two had completed elementary school, four had uncompleted high school, two had complete high school, and two had incomplete higher education.

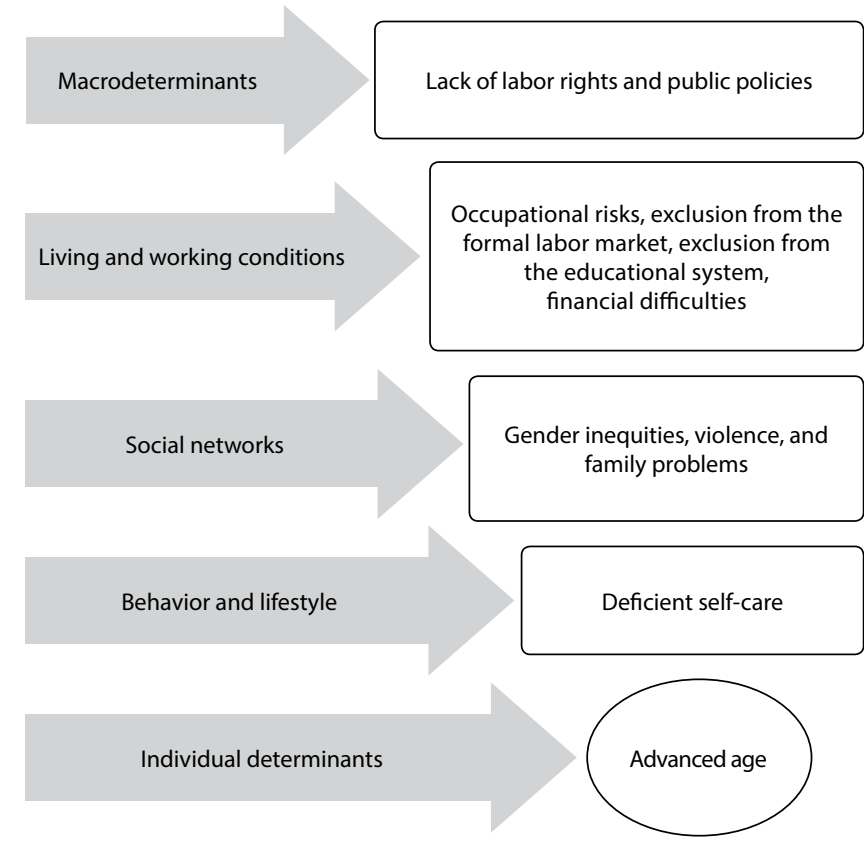

Figure 1 - Synthesis of the social determinants of health evidenced in the context of life and work of waste pickers according to the Dahlgren and Whitehead model, Palmeira das Missões, State of Rio Grande do Sul, Brazil, 2020

The average working time in the associations was 6.7 years, and, in recycling in general, eight years. The majority of workers $(n=15)$ reported having suffered work accidents, especially cuts, falls, punctures, sprains, and bruises. Most $(n=17)$ reported having some form of chronic illness. 
Regarding the family composition, it was heterogeneous. Most $(n=11)$ reported living with a partner and/or child(ren). Seven workers had extended families, including partners, child(ren), sons-in-law, daughters-in-law, mothers-in-law, fathers-in-law, nephews, fathers, and mothers. One worker reported living alone. Food: most workers said to eat three or more meals a day $(n=15)$.

Regarding the SDOHs established in the life circumstances and work of waste pickers, their synthesis can be visualized in Figure 1, represented according to Dahlgren and Whitehead's model. Next, we show the analytical categories derived from the analysis used in this study.

\section{Individual and family trajectories demarcated by social determinants of health}

The data of this category shows the SDOHs of the first three layers of the Dahlgren and Whitehead model. Concerning individual determinants (first layer), advanced age proved to be a valuable element for individuals. Regarding behaviors and lifestyle (second layer), deficit self-care was a potential element for their illness:

The burdens are heavy. [...] when we reach a certain age [...] / pushed the bales by myself in the past. I can't today. It starts throbbing here, the vein of the head. (Sonia)

I would say that they are not very careful. [...] People don't use the material [protective equipment] that need be used. The appropriate gloves, the masks, the ear protector [...] people don't take care of themselves. (Johnny Cash)

Regarding social networks (third layer), the family proved to be a space demarcated by gender inequities, violence, and conflicts. In domestic life, some waste pickers reported difficulties in looking for a job due to power relations in marriage:

[...] I was married 18 years to the father of the boys. I had never worked because he wouldn't let me. After I broke up, I forced myself to work, it was hard to find this job [...] He was very jealous of me, he was much older than me. (Clara)

[...] my husband said, "eitheryou stay with me or with your studies." I thought what he said was right, and I was wrong. The marriage did not continue [...]. I regret it because I didn't realize it before. [...]. (Paloma)

Complex family relationships involving living with family members had a prominent position in the speech of the waste pickers regarding their life itinerary:

[...] it seems that the people who live with me don't take me for granted. It seems that my children do not take me for granted, the difficulties that I face here. My husband is unemployed, I am supporting the house. I just cannot understand why they don't wash a cup to help me, they don't wash dishes, they don't do the laundry. [...] I have problems with my partner, he drinks, bothers all night [...]. (Marlene)

[...] many of these people have complex family issues, mainly related to children dependent on licit or illicit drugs; involvement with trafficking; children arrested for recurrent crimes; unwanted pregnancy of close family members; interpersonal conflicts within the family that culminate in aggression and the early departure of adolescents from home; and domestic violence. The suffering is expressed in the speech of these participants, highlighting the problems they use to face. I note that vulnerability is an extensive field and is not restricted to work, impacting other dimensions of life, especially family relationships. (ON, 09/05/2017)

Violence was present in the life trajectory of women and their dependents, including an allusion to an attempt at femicide:

[...] my separation was very uncomfortable because he attacked me, and I had to leave my house. [...] I started life from scratch because he got all my belongings [...]. (Clara)

[...] / could suffer, but I didn't want them [children] to suffer. When he beat my children, and I got home from work, their pain ached together in my soul, because I was not at home to protect them. And they were beaten brutally, went black-eyed to school. [...] He chased me for five years [ex-husband]. He said: "I leave jail, but you won't leave the cemetery. You'll never get rid of the six feet under". And he tried to kill me. I'm here today because I think God had a plan for me. (Paloma)

\section{Living and working conditions and the interface with macro-determinants}

This analytical category demonstrates how living and working conditions (fourth layer) and some macro-determinants (fifth layer) were evidenced in the testimonies of the waste pickers. The reports of life trajectories begin emphasizing picking work because of the few opportunities for formal education, with life stories permeated by many difficulties in different spheres. They started recycling as a resource in the face of unemployment and as a source of income for the survival of the children:

I studied until the 2nd grade. It didn't have much appeal. My parents lived out [rural area] and didn't even care. The school was far away, we only went when we could. I had no way to keep up with the class. (Luana)

I did not get more places at that time. Then I stopped and gave up in the end. I didn't want to give up studying. (Alessandra)

I raised my kids by pulling cart [recycling collection] until they grow up. My ex-husband had no job. (Marlene)

Also, the data allow us to identify a set of challenges faced by workers in the daily life of the picking, such as occupational risks:

[...] I think that we are very exposed in this work [...] We work with the garbage that comes from the population. And I think it's risky. [...]. (Madalena)

[...] I have observed, among the recyclable materials, objects such as tapes used to check blood-contaminated capillary blood glucose; insulin administration syringes; sharps in general; toilet paper contaminated by feces, urine, or blood; organic waste of all kinds; decomposing dead animals. In addition, the recyclable 
material often contains urine and feces of dogs, cats, and rats, which circulate freely in the shed, among the materials handled by the workers. (ON, 08/18/2017)

The risky exposure of the participants to the recyclable occurs mainly due to the quality of the material that is disposed of by the population to selective collection:

[...] people have no idea that those who work here are human too, they get sick too. We always find syringes with needles, [...] serum needle, the blood-stained sleeves [...]. Toilet paper, dead chicken, dead cat. I think all of this will appear in a while [illness]. I took an examination and the doctor thinks I have hepatitis, and where did I get a hepatitis? [...]. (Marlene)

The data show that the work of the waste pickers of recyclable material is intense and exposes them to daily discomfort, causing impacts, including, on their health. From the testimonies and observation notes, we could realize that work-related labor damages can compromise the quality of life of workers. Among these damages, physical pain is the most reported by the participants.

[...] There are days when I get up, you know that song that the children sang, merry-go-round, from the tin doll, untie here, untie there [...]. I keep thinking about that song. I get up like this, with pain [...]. (Joana)

Throughout the performance of the systematic participant observation, pain is a recurrent complaint, especially pain in the lower limbs and spine, for which they usually self-medicate with oral drugs based on paracetamol. (ON, 09/08/2017)

We complement that, in addition to the risks present in the daily work, some statements pointed to the lack of labor rights and public policies, which signals some macro-determinants:

[...] the lack of Public answer. The government could make recycling a much better thing, to receive many more people to work [...]. (Simoniti)

[...] It seems that they don't care about the people who are working there. If we get sick, we won't be entitled to have work rights. We will have to stay at home without earning anything [...]. (Clara)

[...] there is no Government Severance Indemnity Fund here, there are any rights, no extra money you know you will get, so I'm looking for [another job]. For me, this is important because it is my life that is running. (Madalena)

\section{DISCUSSION}

The first thematic category showed SDOHs connected to individual factors of recyclable material waste pickers, starting with the first layer, represented by the individual determinants. Advanced age proved to be an essential and particular element, considering that the picking work requires intense mobilization of the body to perform the tasks. A literature review study corroborates this finding, showing that advanced age for waste pickers often represents an increase in physical symptoms, such as pain ${ }^{(4)}$. We can also highlight the pattern according to which age correlates inversely with productivity, in other words, the higher the age of the subject, the less productive he is for society. It reinforces inequalities in terms of opportunities in the context of work.

The second layer is composed of determinants related to behaviors and lifestyle, and poor self-care was evident in the testimonies. It goes against other studies, which show that waste pickers of recyclable materials sometimes do not adequately protect themselves against occupational risks ${ }^{(16)}$ and do not have sufficient self-care actions to avoid accidents or occupational illness ${ }^{(4)}$. This finding shows that health services need to pay attention to these issues to produce educational strategies that sensitize this group of workers about the importance of care in their work process.

The third layer of SDOHs highlights social support networks, whose potential for cohesion is relevant for the health of the individuals ${ }^{(11)}$. This study revealed that such networks are weakened by the experiences of gender inequality, violence, and conflicts in the home space.

These elements, when presented among the SDOHs of the waste pickers, accentuate the asymmetrical power relationships between men and women in different ways. More clearly, this is seen in reports of physical aggression and even attempted femicide. However, the different faces of violence are also present in the imprisonment of women in the domestic space, when they are prevented from working or studying; in financial and property losses; in the unequal division of domestic responsibilities and with children; in the establishment of abusive patterns of relationship.

Within this subject, we can cite a Brazilian research that identified a significant association between women who suffered two or more types of violence and low education - the latter is also described in the present study. Although women of all educational levels are victims of violence, what differentiates them is that the most educated have greater autonomy, reducing tolerance to aggression ${ }^{(17)}$.

Gender violence in the Latin American context is a phenomenon of wide proportion. It reflects an unequal power dynamic that is perpetuated in the binary system of gender and is perpetrated by the individual who puts himself as a physical, cultural or social advantage over the other - usually, the man over the woman ${ }^{(18)}$.

Gender-based violence causes physical and psychological damage to its victims ${ }^{(19)}$, which reveals the importance of reflection on the interrelationship between violence and health ${ }^{(20)}$. The reports indicate that the violence expressed, especially in the gender component, is related not only to the loss of property and material resources but also to emotional damage. In this sense, violence constitutes an essential factor of vulnerability for these people since it represents the delimitation of critical moments of their lives that make up their trajectory and their identity.

In the second analytical category, we revealed the SDOHs of a more collective order, mainly represented by working living conditions (fourth layer) and some macro-determinants(fifth layer) ${ }^{(11)}$. The testimonies indicate that the difficulties in access to education and, consequently, to formal employment culminated in the migration of these people to work with recyclable material.

The literature describes the waste pickers of recyclable material as a population group of low economic power and attached to 
vulnerability contexts ${ }^{(21)}$. For example, a qualitative study carried out with associated women waste pickers showed that they had life trajectories marked by economic, family, and social vulnerabilities. Child labor, exclusion from the formal labor market, racial and gender inequalities were common elements in the respondents' discourse. We concluded that the issues of race and gender were crucial determinants of life of this group ${ }^{(22)}$, which integrates and corroborates both analytical categories of the present work.

The study also revealed a precarious work of waste pickers: unstable, informal, and unstable work is one of the contemporary employment arrangements in the world whose negative consequences for the health of workers are evident ${ }^{(23)}$. The findings of the on-screen study refer to intense and exhaustive work related to daily discomforts. In the literature, we can observe the hardness that characterizes the work of waste pickers in associations, highlighting the exposure to heat, cold, and rain, as well as the need for frequent physical exertion, with a consequent feeling of exhaustion. Daily life in recycling sheds requires workers an intensive mobilization of physical, mental, and emotional capacities to meet an exhausting demand for work ${ }^{(8)}$.

Recent national and international studies have shown that the waste-pickers work exposes them to a range of risks of occupational diseases and accidents. Concerning occupational diseases, there is evidence of the high incidence of musculoskeletal disorders, chronic non-communicable diseases (arterial hypertension and diabetes mellitus), infectious diseases, verminous diseases, and allergic diseases in this population. Long working hours, combined with lack of access or non-use of personal protective equipment, aggravate the risk of illness at work ${ }^{(7,9,21)}$.

A study of mixed methods with recyclable material pickers found a significant statistical association between the occurrence of vector-borne diseases (dengue, Zika, and Chikungunya) and the variables: the place of residence, working conditions, use of personal protective equipment, and weekly working hours ${ }^{(24)}$. Also, there is evidence of a high incidence of hepatitis $B, C$, and $E$ in this population ${ }^{(9,25)}$. These data confirm the accounts of the depositors, showing that work with recyclable material is an important $\mathrm{SDOH}$, which results in compromising their quality of life and their family.

Occupational accidents among waste pickers are also prevalent, including cuts, burns, skin and eye injuries, limb and head injuries, and sometimes amputations. Accidents with piercingcutting material are common ${ }^{(7,9,21)}$.

Also, pain, an aggravation issue that obtained emphasis in the respondents' discourse, is also evidenced in the literature. An integrative review study described that waste pickers of recyclable material live with high risks of musculoskeletal injuries, especially in the upper limbs, spine, and shoulders. These risks are aggravated with advancing age and with the duration of work $^{(9)}$, and are related to inadequate working conditions, such as organizational factors, mechanical efforts, and fatigue ${ }^{(26)}$.

It is noteworthy that the waste pickers of recyclable material, throughout a life marked by deprivation and difficulties, find in this work, although little valued, their survival and their family in many cases. Generally, they comprise a segment socially unassisted, invisible to society and Public Power ${ }^{(27)}$. It goes against the statements that end the second analytical category, signaling for a macro-determinant (fifth layer) ${ }^{(11)}$, because it is a reflection of a scenario of the absence of public policies capable of ensuring rights and security to the informal worker, especially those who work in recycling.

Waste picker associations are a key link for sustainable solid waste management. They play a crucial social, economic and environmental role. However, because they have as their primary source of savings the public sector and because of the difficulties of self-management, recycling associations often fail to achieve a competitive position in the recycling market ${ }^{(28)}$. The low remuneration received by them contributes to the maintenance of cycles of poverty and inequalities. Therefore, these subjects need effective public policies, in addition to greater recognition of the population about the importance of their work ${ }^{(27)}$.

The results of this study reinforce the understanding that public policies aimed at groups of waste pickers can and need to be strengthened, considering the SDOHs that involve the context of work and life of these people. Waste pickers may never enjoy a risk-free work environment, despite public policies and support institutions may help mitigate these problems and create a sustainable and dignified work environment ${ }^{(1)}$.

\section{Limitations of the study}

As a limitation of this study, we can mention that the waste pickers of recyclable material are a population of difficult access. They generally have little time to participate in qualitative research since their financial gains result from daily production. It limited the length of interviews and, consequently, the depth of the data obtained. In addition, not all people interviewed felt comfortable talking about critical events in their lives, a limitation that we expect when addressing personal topics. However, these limitations did not severely compromise the quality of the data that we obtained.

\section{Contributions to the nursing area}

The concept of SDOH provides the understanding that the social and economic conditions that surround people's lives (such as gender and race inequities, poverty, little access to education and social mobility, as well as precarious work) profoundly impact their health and illness dynamics. Recognizing the relationship between these elements potentiates interventions to reduce health inequities deeply rooted in society; it also contributes to better evidence-based decisions that promote transformations in the health indicators of vulnerable populations ${ }^{(29)}$.

The results of this study are relevant concerning the construction of nursing care in vulnerable groups, such as waste pickers of recyclable material. This production of care needs to be sustained by actions of support, help, autonomy, comfort, education, damage limitation, disease prevention, and health promotion. Thus, if the daily nursing practice does not make the individual understand the SDOHs to meet their needs and outline care plans, we will continue to reinforce the curative models restricted to the containment of the disease and without the power to transform in the face of complex contexts ${ }^{(12)}$. 


\section{FINAL CONSIDERATIONS}

The waste pickers of recyclable material had individual and family trajectories demarcated by the SDOHs. Advanced age, poor self-care, gender inequities, violence, and family conflicts emerged as elements linked to individual, behavioral and social network determinants.

Also, the determinants related to living and working conditions were connected to poor access to education and formal work. In the daily life of the cupping, the workers faced occupational risks, which culminated in damage to their health. Finally, the statements signaled some macro-determinants, represented by the lack of labor rights and public policies. At the end of this study, it was possible to conclude that social and economic deficiencies are potentiated in the context of life and work of waste pickers, strongly relating to their determinants.

For future research, we recommend that non-associated or cooperative recyclers of recyclable material be investigated, such as those who operate on the streets with human or animal propulsion carts and whose SDOHs can be differentiated. Also, we suggest that the search for SDOHs in the context of other vulnerable populations, under the lens of health and nursing research.

\section{FUNDING}

This work was carried out with the support of the Coordination for the Improvement of Higher Education- Personnel - Brazil (CAPES) - Funding Code 001.

\section{ACKNOWLEDGEMENTS}

Our thanks to Prof. Dr. Mercedes Trentini, whose contributions were fundamental to the quality and rigor of this work.

\section{SUPPLEMENTARY MATERIAL}

Coelho APF. The self-care of recyclabe material collectors: convergent-care research. Thesis (Doctorate in Nursing) - Universidade Federal de Santa Maria. Santa Maria, RS, Brasil, 2018. Available from: https://repositorio.ufsm.br/handle/1/14614

\section{REFERENCES}

1. Schenck CJ, Blaauw PF, Viljoen JM, Swart EC. Exploring the potential health risks faced by waste pickers on landfills in South Africa: a socioecological perspective. Int J Environ Res Public Health. 2019;16(11):2059. https://doi.org/10.3390/ijerph16112059

2. Martínez L, Zuluaga B, Prada SI. Analyzing factors associated with trash pickers' health status: census data in a major city in Colombia. J Community Health. 2019;45:133-40. https://doi.org/10.1007/s10900-019-00725-7

3. Dagnino RS, Johansen IC. Os catadores no Brasil: características demográficas e socioeconômicas dos coletores de material reciclável, classificadores de resíduos e varredores a partir do censo demográfico de 2010 [Internet]. Rio de Janeiro; IPEA, 2017 [cited 2020 Jun 20 ]. Available from: http://repositorio.ipea.gov.br/bitstream/11058/7819/1/bmt_62_catadores.pdf

4. Coelho APF, Beck CLC, Silva RM. Health conditions and illness risk of recyclable material collectors: an integrative review. Cienc Cuid Saude. 2018;17(1):1-9. https://doi.org/10.4025/cienccuidsaude.v17i1.37464

5. Poole CJM, Basu S. Systematic review: occupational illness in the waste and recycling sector. Occup Med. 2017;67(8):626-36. https://doi. org/10.1093/occmed/kqx153

6. Cruvinel VRN, Zolnikov TR, Bashash M, Marques CP, Scott JA. Waterborne diseases in waste pickers of Estrutural, Brazil, the second largest open-air dumpsite in world. Waste Manag. 2019;99:71-8. https://doi.org/10.1016/j.wasman.2019.08.035

7. Cruvinel VRN, Marques CP, Cardoso V, Novaes MRCG, Araújo WN, Angulo-Tuesta A, et al. Health conditions and occupational risks in a novel group: waste pickers in the largest open garbage dump in Latin America. BMC Public Health. 2019;19(1):581. https://doi.org/10.1186/s12889-019-6879-x

8. Coelho APF, Beck CLC, Fernandes MNS, Prestes FC, Silva RM. Work risk related to illness and defensive strategies of collectors women's waste recyclable. Esc Anna Nery. 2016;20(3):e20160075. https://doi.org/10.5935/1414-8145.20160075

9. Coelho APF, Beck CLC. Production about the health of the gatherer of recyclable materials: a study of trends. Rev Enferm UFPE. 2016;10(7):2747-55. https://doi.org/10.5205/1981-8963-v10i7a11336p2747-2755-2016

10. World Health Organization (WHO). Health in all policies: training manual [Internet]. 2015 [cited 2018 Aug 02]. Available from: http://apps. who.int/iris/bitstream/handle/10665/151788/9789241507981_eng.pdf?sequence=1

11. Dahlgren $G$, Whitehead M. Policies and strategies to promote social equity in health. Background document to WHO - Strategy paper for Europe. Stockolm: Arbetsrapport/ Institutet for Framtidsstudier [Internet]. 2007 [cited 2017 Mar 07];14:01-69. Available from: http://www. iffs.se/media/1326/20080109110739filmZ8UVQv2wQFShMRF6cuT.pdf

12. Salcedo-Álvarez RA, Zárate-Grajales RA, González-Caamaño BC, Rivas-Herrera JC. The social determinants of health: the case of nursing. Rev Enferm Inst Mex Seguro Soc [Internet]. 2017 [cited 2018 Aug 02];25(2):139-44. Available from: http://revistaenfermeria.imss.gob.mx/ editorial/index.php/revista_enfermeria/article/view/112/367

13. Porter K, Jackson G, Clark R, Waller M, Stanfill AG. Applying social determinants of health to nursing education using a concept-based approach. J Nurs Educ. 2020;59(5):293-6. https://doi.org/10.3928/01484834-20200422-12

14. Trentini M, Paim L, Silva DMGV. Pesquisa Convergente-Assistencial - PCA: delineamento provocador de mudanças nas práticas de saúde. Porto Alegre: Moriá; 2014. 
15. Fontanella BJB, Luchesi BM, Saidel MGB, Ricas J, Turato ER, Melo DG. Sampling in qualitative research: a proposal for procedures to detect theoretical saturation. Cad Saúde Pública. 2011;27(2):389-94. https://doi.org/10.1590/S0102-311X2011000200020

16. Thakur P, Ganguly R, Dhulia A. Occupational health hazard exposure among municipal solid waste workers in Himachal Pradesh, India. Waste Manag. 2018;78:483-9. https://doi.org/10.1016/j.wasman.2018.06.020

17. Vieira LJES, Ferreira RC, Moreira GAR, Gondim APS, Araújo MAL, Silva RM. Factors associated to the imposition of types of violence against women informed in sentry services. Rev Latino-Am Enfermagem. 2013;21(4). https://doi.org/10.1590/S0104-11692013000400013

18. Tsapalas D, Parker M, Ferrer L, Bernales M. Gender-Based Violence, Perspectives in Latin America and the Caribbean. Hisp Health Care Int. 2020;19(1). https://doi.org/10.1177/1540415320924768

19. Batista VC, Marcon S, Peruzzo HE, Ruiz AGB, Reis P, Silva ANM, et al. Prisoners of suffering: perception of women on violence practiced by intimate partners. Rev Bras Enferm. 2020;73(Suppl 1):e20190219. https://doi.org/10.1590/0034-7167-2019-0219

20. Schneider D, Signorelli MC, Pereira PPG. Public security female workers at the coast of Paraná, Brazil: intersections of gender, work, violence(s), and health. Ciênc Saúde Colet. 2017;22(9):3003-11. https://doi.org/10.1590/1413-81232017229.07892016

21. Zolnikov TR, Ramirez-Ortiz D, Moraes H, Cruvinel VRN, Dominguez A, Galato D. Continued medical waste exposure of recyclable collectors despite dumpsite closures in Brazil. J Health Pollut. 2019;9(23):190905. https://doi.org/10.5696/2156-9614-9.23.190905

22. Coelho APF, Beck CLC, Silva RM, Vedootto DO, Silva JRP. Female work and health in the perspective of women recyclable waste collector. Texto Contexto Enferm. 2018;27(1):e2630016. https://doi.org/10.1590/0104-07072018002630016

23. Puig-Barrachina V, Vanroelen C, Vives A. Measuring employment precariousness in the European Working Conditions Survey: the social distribution in Europe. Work. 2014;49(1):143-61. https://doi.org/10.3233/WOR-131645

24. Cruvinel VRN, Zolnikov TR, Takashi Obara M. Vector-borne diseases in waste pickers in Brasilia, Brazil. Waste Manag. 2020;105:223-232. https://doi.org/10.1016/j.wasman.2020.02.001

25. Souza-Silva G, Mol MPG. Hepatitis B or C prevalence in waste pickers from South America: a systematic review. J Public Health. 2020;fdaa065. https://doi.org/10.1093/pubmed/fdaa065

26. Ministério da Saúde (BR). Comissão Nacional sobre Determinantes Sociais da Saúde. As causas sociais das iniquidades em saúde no Brasil. [Internet]. 2008 [cited 2020 Jul 14] Available from: http://bvsms.saude.gov.br/bvs/publicacoes/causas_sociais_iniquidades.pdf

27. Braga NL, Lima DMA, Maciel RH. "Surviving only of mercy": the experience of recyclable material collectors. CES Psicol [Internet]. 2016 [cited 2020 Jun 20];9(1):122-34. Available from: http://www.scielo.org.co/pdf/cesp/v9n1/v9n1a09.pdf

28. Siman RR, Yamane LH, Baldam RL, Tackla JP, Lessa SFA, Britto PM. Governance tools: Improving the circular economy through the promotion of the economic sustainability of waste picker organizations. Waste Manag. 2020;105:148-169. https://doi.org/10.1016/j. wasman.2020.01.040

29. Galea S, Abdalla SM, Sturchio JL. Social determinants of health, data science, and decision-making: Forging a transdisciplinary synthesis. PLoS Med. 2020;17(6):e1003174. https://doi.org/10.1371/journal.pmed.1003174 